\title{
The costs of beekeeping for pollination services in the UK? An explorative study
}

Article

Accepted Version

Breeze, T. D., Dean, R. and Potts, S. G. (2017) The costs of beekeeping for pollination services in the UK? An explorative study. Journal of Apicultural Research, 56 (3). pp. 310-317. ISSN 0078-6913 doi:

https://doi.org/10.1080/00218839.2017.1304518 Available at https://centaur.reading.ac.uk/69535/

It is advisable to refer to the publisher's version if you intend to cite from the work. See Guidance on citing.

To link to this article DOI: http://dx.doi.org/10.1080/00218839.2017.1304518

Publisher: Taylor \& Francis

All outputs in CentAUR are protected by Intellectual Property Rights law, including copyright law. Copyright and IPR is retained by the creators or other copyright holders. Terms and conditions for use of this material are defined in the End User Agreement.

\section{www.reading.ac.uk/centaur}

\section{CentAUR}

Central Archive at the University of Reading 
Reading's research outputs online 
1 The Costs of Beekeeping for Pollination Services in the UK 2 an Explorative Study

Breeze T.D. ${ }^{1 *}$, Dean R. ${ }^{1,2}$ and Potts S.G. ${ }^{1}$

${ }^{1}$ Centre for Agri Environmental Research, School of Agriculture, Policy and Development, University of Reading, Reading RG6 6AR, UK

${ }^{2}$ Redbeehive Company, 51, Elm Road, Bishops Waltham, Southampton, SO32 1JR, UK

\section{Summary}

Honeybees are a key managed pollination service resource in crop agriculture, providing flexible, highly generalist and resilient pollination service delivery to a broad range of UK crops. Despite their potential economic impacts there is little information on the actual costs involved in providing pollination services experienced by UK beekeepers. Utilising an online survey of UK beekeepers, this study examines the full economic costs of providing pollination services to crops in the UK, as well as examining the differences in costs experienced by different beekeepers. The findings indicate that $<10 \%$ of respondent beekeepers, mainly professionals, actively provide pollination services to crops and rarely receive payment for this in field crops. In apple orchards, where beekeepers most often receive payments, the benefits to the orchard are estimated at 86149 times the payments received by beekeepers. Although exploratory, the findings highlight the need for wider collection of information on beekeeping costs and several key knowledge gaps that could influence future development of the UK bee farming industry.

Keywords: Pollination services, Honeybees, Economics, management costs

Short title: Costs of Beekeeping in the UK

\section{Introduction}

Pollination services are a key agricultural input that influences the yield of $\sim 75 \%$ of global crops (Klein et al., 2007). In the UK, insect pollinated crops account for $\sim 20 \%$ of planted crop area and pollination services were estimated to contribute $f 691 \mathrm{M}$ to the production of these crops in 2011 (Vanbergen et al., 2014). Although pollination services are often primarily provided by wild insect communities (Garratt et al, 2016; Garibaldi et al, 2013), in large commercial systems managed pollinators, such as the European Honeybee (Apis mellifera), are often used to ensure stable service supply by maintaining a high abundance of pollinators throughout the flowering period (Rader et al, 2009; Delaplane and Mayer, 2000). Furthermore, as managed insects, honeybee colonies are less vulnerable to several pressures affecting wild pollinators (Winfree et al, 2010). As such, honeybees can provide effective insurance in case of wild pollinator losses, and effective service provision where wild pollinator populations are sub-optimal.

Despite the significant economic benefits of pollination services to crop growers (Garratt et al., 2014, 2016), and substantial costs incurred by providing pollination services (Rucker et al., 2012), evidence suggests few beekeepers are compensated for providing pollination services, limiting incentives to provide hives for pollination (Carreck et al, 1997). Furthermore, the estimated capacity of UK honeybee stocks to supply pollination services is only $20 \%$ of total demands (Breeze et al, 2014). This mismatch is confounded by continuing pressures on UK honeybee populations such as 
pests and diseases (Wilfert et al, 2016), fluctuations in forage availability (Baude et al., 2015), cumulative exposure to chemical insecticides (Godfray et al., 2014, 2015) or a combination thereof (Doublet et al, 2015; Pettis et al, 2012). As a result, UK colony numbers have suffered between $10 \%$ and $33 \%$ overwintering losses over the last decade, although the rate of loss has generally trended downwards (BBKA, 2016).

Despite concerns about pollination service provision, rising honey prices and stable total demand (FAO, 2016a,b; FERA, 2013), to date, the specific costs of beekeeping, particularly those involved in supplying hives for pollination services in the UK, have received little research attention and are routinely collected alongside other farming statistics. Understanding the costs of honeybee management could provide better targeted funds to reduce the costs in beekeeping at both an amateur and professional level and help develop more incentivising payment structures for pollination service provision and a more profitable UK honey market. It is generally expected that professional beekeepers will receive greater payments than amateurs and operate at a greater net profit. Using an web-based survey, this study examines: (i) the monetary and opportunity costs of providing pollination to four key insect pollinated crops (apples, strawberries, oilseed rape and field beans); and, (ii) the relative monetary benefits of pollination to crop production compared to payments and honey received from providing these services.

\section{Methods}

\subsection{Surveys}

The costs involved in beekeeping were assessed via online surveys of professional and amateur beekeepers between March and September 2013. Beekeepers were sampled via beekeeper association mailing lists; the Bee Farmers Association (BFA) and 237 UK local beekeeping associations were approached in March 2013 and asked to invite their members to participate. Reminders were sent to associations that did not explicitly reply in May and July 2013. In total 120 associations ( $51 \%$ of associations approached) responded with $>75 \%$ agreeing to participate by circulating the survey link. Due to the limited available population from which to draw samples, a pilot study was not conducted. Questions were framed to remain as anonymous as possible and no personal information was collected.

The survey (Appendix 1) was divided into three sections: 1 ) a series of questions relating to the beekeeper's expertise and area of operations 2) questions relating to their general beekeeping costs and honey production and 3 ) the costs incurred by supplying hives to provide pollination services to four UK crops; apples, strawberries, oilseed rape and field beans. These crops were selected due to their significance to UK crop agriculture, representing the most widespread insect pollinated fruit (apples, strawberries) and arable (oilseed rape, field beans) crops in the UK (DEFRA, $2016 a, b)$. For general beekeeping costs, respondents were asked to state i) the cost of equipment over the last 3 years, ii) the amount spent on new queens over the last 3 years, iii) the annual costs per hive of disease management, iv) the typical annual costs for controlling colony swarming and $v$ ) the average monthly production of honey per hive they were able to achieve over the last 3 years. The three year time span was chosen to reduce the impacts of recent years with abnormally high or low costs while not alienating newer beekeepers. Crop specific costs were defined as the costs of i) labour, ii) transportation, iii) the depreciation value from lost colony strength and iv) any other costs particular to providing pollination service to the crop (e.g. supplemental feed required). Respondents were also asked to state the amount of honey produced from each crop and their 
estimates of depreciation (if any) in honey producing strength (as a \%) from the management of the hive for pollination in the crop.

\subsection{General beekeeping costs}

Costs were calculated for each respondent based on their responses to the questionnaire. In order to preserve the anonymity of large beekeeping professionals, respondents were not asked to state how many colonies they manage, only broad categories. As such, estimated costs per hive are given based on the median number of hives in each category, taking 250 as the value for those responding $>200$. Appendix 2 presents these estimates using the lowest and highest values form each category. The value of honey production reported by each respondent was estimated using the average regional price/kg reported in FERA (2011), multiplied by 4 for the number of productive months in the year, as appropriate for each respondent.

\subsection{Costs of providing pollination services}

Based on their responses the economic costs incurred by each respondent (i) of providing pollination services to each crop (c) were estimated as the sum of 1 ) the crop specific costs of providing pollination services, 2 ) opportunity costs $(O)$ of pollination compared to honey production (Eq. 1), 3) the depreciation (DP) of the hive's honey producing strength (Eq. 2) and 4) the costs of transporting hives ( $T$, Eq. 3). Opportunity costs are not calculated for apples as apple flowering typically occurs before the honey producing season.

$$
\begin{gathered}
O_{i c}=\left(H_{i c}-\left(\frac{H_{i h}}{4} \times W_{c}\right) H P_{r}\right) \\
D P_{i c}=\left(H_{i h} \times D_{i c}\right) H P_{r} \\
T_{i c}=\frac{\left(2 S_{i c} \times F\right)}{\left(P_{i c} \times N_{i}\right)} G
\end{gathered}
$$

Where $H_{i c}$ is reported honey yield per hive in crop c, $H_{i h}$ is reported average monthly honey yield from placing hives outside of crop areas, $W_{c}$ is the reported weeks that the hive is placed in the crop. Where a hive is reported as being permanently located by a crop, the value of $W_{c}$ is changed to fit standard flowering durations (4 weeks in apples, 8 weeks in field beans and oilseed rape). $H P_{r}$ is the price per kilo of honey in region $r, D_{i c}$ is the reported loss of honey producing colony strength from placing the hive in crop $c, 2 S_{i c}$ is double the reported distance travelled to each crop (representing pick up and collection) and $F$ is the price per kilometre of petrol for a large van. This based on the average extra urban mile per gallon of large vans registered with the Vehicle Certification Agency (VCA, 2016), converted into km per litre and multiplied by the 2012 average price per litre of diesel (ONS, 2014) - $£ 0.17 / \mathrm{km}$. $P_{i c}$ is the proportion of respondent hives loaned or rented to a crop and $\mathrm{Ni}$ is the lower bound number of hives that a beekeeper supplies to a crop. $G$ is a weight parameter use to prevent large numbers of colonies having unrealistically low transport costs. $G$ has an interger value of 1 for every 25 (or part thereof) hives moved to the crop, representing either multiple trips or hire of larger vehicles. The relationships between different background variables (years of beekeeping experience, number of beehives managed, professional or amateur status and management for honey or pollination services) were explored in $\mathrm{R}$ with Pearson's product moment correlation analysis following Shippiro-Wilks test for normality. 


\subsection{Economic benefits of honeybee pollination}

To assess the relative benefits of crop pollination services from honeybees hives to apples, three measures of economic benefit were estimated i) additional economic output per hive, estimated by dividing the net economic benefits of pollination services per hectare of four common varieties of apples (Garratt et al, 2016) by 3.6, the average recommended stocking rate of honeybee colonies per hectare reported in Breeze et al (2014). This assumes that the stocking rate is adequate to provide pollination services equal to current levels and that there is a linear relationship between stocks and benefits. Secondly, these estimated benefits per hive were then divided by the average payments per hive reported by survey respondents to produce a benefits:cost ratio for growers. Finally, the benefits per hive were divided by the average net gains economic gains (fees paid + honey produced) per hive reported by beekeepers.

\section{Results}

\subsection{Response}

In total 343 beekeepers provided usable responses, of which the majority $(314 ; 92 \%)$ were amateurs with only $8 \%(29)$ of respondents identifying as professional beekeepers. This represents $1.1 \%$ of beekeepers registered with the national bee unit in 2013 (FERA, 2013). Although the low sample size of professionals limits statistical comparison analysis of this information some differences are apparent. Notably, professionals typically had $>50$ hives (86\%) and had been keeping bees for $>20$ years $(59 \%)$ compared to amateurs who almost always managed $<20$ hives $(94 \%)$ and usually had $<5$ years beekeeping experience (53\%). Respondents were mainly based in South East or Western England ( $52 \%$ in total). Many Northern and Scottish beekeeping associations felt the survey was of limited interest to their members given the limited area of pollinated crops planted in these regions. There were strong correlations between professionals and both years of beekeeping $(r=0.35, p<0.001)$ and number of hives $(r=0.87, p<0.001)$ as well as years beekeeping and number of beehives $(r=0.41, p<0.001)$.

\subsection{Costs of Beekeeping}

General beekeeping costs varied strongly across respondents, with no clear relationships between demographic variables. Due to the relatively small sample and high standard deviation in much of the data, discussion of the results focuses on median, rather than average costs. Median queen costs and swarming were both $f 0$ indicating that most beekeepers have not experienced these expenses over the last 3 years (219 and 230 respondents respectively). Among both groups of beekeepers, disease management costs accounted for an average of $\sim 62 \%$ of the estimated total costs/hive. Respondents who identified as mainly managing for honey production did not report higher honey yields than other respondents. Based on respondents answers, Tukey tests indicate that total equipment costs are lower for the most experienced beekeepers (those with $>20$ years' experience) compared to all other experience categories (Appendix $2, \mathrm{p}<0.001$ ). Furthermore. total swarming costs are substantially higher for professionals $\left(f_{1,344}=31.89, p<0.001\right)$ which Tukey tests indicate are driven by the higher numbers of colonies (appendix $2, p \leq 0.001$ ). On a per-hive basis, amateurs had significantly higher costs for queens than professionals $\left(f_{1,341}=5.685, p=0.017\right)$. This is likely to be an effect of beekeeping experience, which Tukey tests indicate are significantly lower for beekeepers with $>20$ years' experience compared to those with $6-10$ years $(t=-3.045, p=0.0199)$, 
and $\leq 5$ years' experience ( $t=-2.738, p=0.047$ ). Comparing the total costs of queens reported by respondents, there are only significant differences between the most experienced ( $>20$ years) beekeepers and those who have $6-10$ years beekeeping experience ( $t=3.063, p=0.017)$, while by contrast the number of hives a beekeeper manages did not significantly affect their queen costs. Honey production per hive was only significantly greater between the most and least experienced beekeepers ( $t=7.3565, p=0.023)$. In total, median annual costs were estimated at $f 27.00 /$ hive, although this falls by $\sim 57 \%$ to $f 11.87 /$ hive once the annual value of honey is considered.

Table 1 Detailed breakdown of annual costs per hive for professional and amateur beekeepers

\begin{tabular}{lrrrrrrrrr}
\hline & \multicolumn{3}{c}{ Amateur $(\mathrm{n}=314)$} & \multicolumn{2}{c}{ Professional $(\mathrm{n}=29)$} & \multicolumn{2}{c}{ All $(\mathrm{n}=343)$} \\
\hline & Average & \multicolumn{1}{c}{ S.D. } & Median & Average & S.D. & Median & Average & S.D. & Median \\
\hline Queens & $£ 0.27$ & $£ 0.55$ & $£ 0.00$ & $£ 0.03$ & $£ 0.05$ & $£ 0.01$ & $£ 0.25$ & $£ 0.53$ & $£ 0.00$ \\
Equipment & $£ 12.38$ & $£ 18.67$ & $£ 6.67$ & $£ 10.30$ & $£ 18.03$ & $£ 2.22$ & $£ 12.20$ & $£ 18.60$ & $£ 6.67$ \\
Swarming & $£ 2.55$ & $£ 8.13$ & $£ 0.00$ & $£ 5.89$ & $£ 16.52$ & $£ 0.02$ & $£ 2.84$ & $£ 9.15$ & $£ 0.00$ \\
Disease & $£ 23.32$ & $£ 23.28$ & $£ 15.00$ & $£ 17.93$ & $£ 17.16$ & $£ 10.00$ & $£ 22.87$ & $£ 22.85$ & $£ 15.00$ \\
Total & $£ 38.53$ & $£ 34.75$ & $£ 27.00$ & $£ 34.16$ & $£ 30.58$ & $£ 20.48$ & $£ 38.16$ & $£ 34.40$ & $£ 27.00$ \\
\hline Honey/month $(\mathrm{kg})$ & 2.87 & 3.28 & 1.81 & 2.74 & 3.01 & 2.00 & 2.86 & 3.25 & 1.81 \\
Honey value $(\mathrm{f})$ & $£ 23.21$ & $£ 26.64$ & $£ 15.47$ & $£ 21.53$ & $£ 23.54$ & $£ 17.06$ & $£ 23.07$ & $£ 26.37$ & $£ 15.47$ \\
Net costs & $£ 15.32$ & $£ 43.41$ & $£ 13.16$ & $£ 15.32$ & $£ 43.41$ & $£ 13.16$ & $£ 12.63$ & $£ 44.91$ & $£ 5.81$ \\
\hline
\end{tabular}

Key Queens, equipment, swarming = one third of the reported three year costs of queens, beekeeping equipment and controlling for swarming divided by the estimated number of hives per beekeeper. Disease $=$ the reported annual costs per hive of controlling for diseases and parasites. Total $=$ the total costs per hive per year. Honey $/$ month $=$ the reported average honey produced per month from each hive over the last 3 years (in $\mathrm{Kg}$ ). Honey value $=4$ times the average monthly honey production multiplied by the costs/kg of honey from FERA (2013). Net costs = total costs - honey value. For the purpose of comparison, respondents that did not report honey harvested are assumed to have a value of 0 .

\subsection{Pollination Service Provision}

Among both professional and amateur beekeepers, the majority (62\%) reported they primarily kept bees for honey production while only $5 \%$ kept hives for pollination services. Of the professional respondents, $27 \%$ reported they either primarily provided bees for pollination services or varied their activities between years. Respondents also reported providing pollination services to a range of other crops including glasshouse vegetable seed production and a range of tree and small fruit crops. No further analysis was conducted for strawberries due to the low number of respondents $(n=6)$ that rented or loaned hives to provide pollination services to this crop.

The greatest median crop specific management costs were reported in apples ( $₫ 5 /$ hive) compared to $£ 3.5 /$ hive for oilseed rape and $£ 0 /$ hive for field beans, although there was substantial variation among these costs (Table 2). Only three amateur beekeepers reported payments for their pollination services while 20 professionals received varying levels of payment. Beekeepers who rented or loaned their hives to crops were more likely to receive payments for providing pollination services to apples ( $57 \%$ of those providing services, median $f 50 /$ hive) than oilseed rape $(11 \%$ of those providing services, median $\mathrm{f} 25 / \mathrm{hive}$ ) and field beans ( $14 \%$ of those providing services, median $£ 32 /$ hive). In apples there were also strong correlations between payments received and transportation costs $(r=0.41, p=0.021)$, however no other cost component correlated with payments in any crops.

Very few beekeepers reported any loss of honey producing colony strength (median $0 \%$ for all three crops) with only $20 \%, 7 \%$ and $6 \%$ reporting any depreciation in honey producing strength. Median estimated weekly honey production per hive was typically lower in crops (apples: $0.09 \mathrm{~kg}$, oilseed rape: $0.51 \mathrm{~kg} /$ week, field beans: $0.43 \mathrm{~kg} /$ week) than non-crop habitat reported by the same 
beekeepers (median 1.15kg/week). However, as little honey production is possible in the early parts of the season and apples themselves produce only small quantities of low sugar nectar, this likely represents only a few small, non-crop nectar sources available at this time of year. Beekeepers generally travelled further to apple orchards (median $11.5 \mathrm{~km}$ ) resulting in substantially higher transport costs.

Table 2 Detailed breakdown of annual costs per hive for professional and amateur beekeepers

\begin{tabular}{|c|c|c|c|c|c|c|c|c|c|}
\hline & \multicolumn{3}{|c|}{ Apples $(n=30)$} & \multicolumn{3}{|c|}{ Oilseed Rape $(n=46)$} & \multicolumn{3}{|c|}{ Field Beans $(n=35)$} \\
\hline & Average & S.D. & Median & Average & S.D. & Median & Average & S.D. & Median \\
\hline Crop-Specific & f7.47 & f9.05 & $£ 5.00$ & f12.59 & f15.99 & $£ 3.50$ & f7.69 & f13.55 & $f 0.00$ \\
\hline Depreciation & $£ 0.26$ & $f 0.69$ & $£ 0.00$ & $£ 0.12$ & $£ 0.5$ & $£ 0.00$ & $£ 0.03$ & $£ 0.13$ & $f 0.00$ \\
\hline Labour & $£ 3.47^{*}$ & £10.44* & $£ 0.00^{*}$ & $£ 1.05$ & £6.08 & $£ 0.00$ & f0.68 & $£ 3.80$ & $£ 0.00$ \\
\hline Transport & f1.34 & $£ 2.27$ & $£ 0.48$ & $£ 0.51$ & $f 1.28$ & $£ 0.14$ & $£ 0.46$ & f1.18 & $f 0.17$ \\
\hline Total & $£ 12.64$ & $f 15.11$ & f8.31 & $£ 13.98$ & f16.68 & $f 6.89$ & $£ 8.64$ & $£ 14.93$ & $£ 0.73$ \\
\hline Honey/week (kg) & 0.74 & 1.27 & 0.09 & 0.74 & 0.70 & 0.51 & 0.67 & 0.77 & 0.43 \\
\hline Honey value (f) & $£ 8.90$ & f18.35 & $f 0.58$ & f9.66 & f10.92 & $£ 4.48$ & f8.93 & $f 12.32$ & f3.10 \\
\hline Weeks supplied & 5.48 & 5.51 & 4.00 & 6.37 & 3.37 & 5.00 & 5.77 & 3.78 & 4.00 \\
\hline Opportunity & NA & NA & NA & $-f 1.01$ & f11.71 & $£ 0$ & $-£ 2.79$ & $f 10.97$ & $-£ 0.17$ \\
\hline Payment** & $£ 27.03$ & f27.6 & $£ 27.5$ & f2.96 & f10.6 & $£ 0$ & $£ 4.9$ & $f 12.98$ & $£ 0$ \\
\hline Net costs & $-£ 14.50$ & f30.53 & $-£ 11.82$ & f10.02 & $f 23.73$ & f9.61 & f0.93 & $£ 20.56$ & $f 0.00$ \\
\hline
\end{tabular}

Key Total costs = the total costs incurred before accounting for honey and payment. Opportunity = the difference in the value of honey produced from the crop and the value of honey potentially produced from areas outside of crop fields; negative values indicate that honey production is greater in the crop than areas outside of crop fields. Payments = the value of payments received for providing hives. Net costs = the final costs of supplying each hive after accounting for honey production (opportunity) and payments received (total costs + opportunity - payments). ${ }^{*}$ a single respondent was excluded from the assessment of labour costs as an extreme outlier. ${ }^{* *}$ It was assumed that beekeepers who responded with NA or left no answer received no payment.

\subsection{Benefit ratios in apple production}

Using an estimate of 3.6 hives/ha to provide optimal pollination services and measures (Breeze et al., 2014) of the net economic benefits of pollination services to four apple varieties in 2012 (Garratt et al., 2016), each hive was estimated to provide between $£ 2,361$ and $£ 4,111$ of additional net output per hectare to four varieties apples (Table 3). Compared with the median payments reported by respondents ( $£ 27.50$ ), this results in between $£ 86-£ 149$ of pollination service benefits per $f 1$ spent on hive rental, depending on the variety of apple.

Table 3 Apple producer gross benefits from optimal honeybee pollination services

\begin{tabular}{l|r|rr}
\hline & Pollination Benefits (£000/ha) & $\begin{array}{r}\text { Benefits/hive } \\
\text { (£/ha) }\end{array}$ & $\begin{array}{c}\text { Benefits:costs } \\
\text { (£/hive) }\end{array}$ \\
\hline Cox & $£ 11.9$ & $£ 3308.9$ & $£ 120.23$ \\
Gala & $£ 14.8$ & $£ 4101.9$ & $£ 149.16$ \\
Braeburn & $£ 8.5$ & $£ 2368.3$ & $£ 86.12$ \\
Bramley & $£ 14.5$ & $£ 4018.9$ & $£ 146.41$ \\
\hline
\end{tabular}

Key: Benefits/hive $=$ the gross value of additional pollination services per hectare of each apple cultivar provided by a single hive. Benefits:costs = the gross value of pollination services provided per hectare of each cultivar per $£ 1$ paid to beekeepers (median payments in Table 2: $£ 22.5$ ). 
Using an online survey of UK beekeepers this study examined the general costs of beekeeping and the specific costs of providing pollination services to three major UK crops (apples, oilseed rape and field beans) for both professional and amateur beekeepers. The findings indicate that a majority (62\%) of beekeeper expense on managing hives comes from pest and disease management. This is likely due to Varroa destructor, a parasitic mite that has become near ubiquitous across the UK and acts as a viral vector (Potts et al., 2010; Wilfert et al., 2016), which several respondents stated as being a significant pressure on their beekeeping activities. Presently, the UK government supports honeybee health through the National Bee Unit who actively monitor maintaining this through the recent National Pollinator Strategy (DEFRA, 2014), leading to the development of disease surveillance network (DEFRA, 2015). However, many treatments for Varroa available within Europe are of limited availability in the UK, requiring a special medical request to be made via a veterinarian in order to be imported from the EU (VMD, 2013). With the recent decision of the UK to withdraw from the EU, changes to these regulations will be required which may facilitate greater access to effective treatments, however further work is required to determine the impacts on beekeeper costs. As historic declines in colonies have been attributed to rising costs reducing the number of professional beekeepers (Potts et al, 2010) and potentially acting as a barrier to amateurs maintaining larger colony numbers. The findings of this study suggest that continued investment and support for honeybee health could significantly reduce the burden of diseases on UK beekeeping. Professional and highly experienced beekeepers had significantly lower equipment costs than other beekeepers, possibly reflecting bulk purchases and the accumulation of equipment over time respectively. However, there was no significant difference in the amount of honey produced per hive by amateur and professional beekeepers. Furthermore, most respondents had no queen or swarming costs, indicating that these costs are infrequent spikes, possibly more infrequent than the 3 year time span captured by this survey. Although the findings of this study are based on reasonable assumptions, more precise information on the number of hives would allow for more refined assessment of these general costs of beekeeping, particularly for amateurs.

\subsection{Costs for pollination services provision}

The specific costs of managing honeybee colonies for pollination services are often relatively small, mostly stemming from crop specific management costs in apples and oilseed rape, although a few larger scale professional beekeepers reported very high labour costs. In contrast with findings by Rucker et al (2012) transportation costs are relatively small, probably due to the shorter distances travelled by UK migratory beekeepers, and few beekeepers report any loss of colony strength, even in apple, a low nectar crop. Similarly, although past studies (Godfray et al., 2014, 2015) have suggested that systemic insecticides may have an impact on honeybee colony health, the very low number of beekeepers reporting any depreciation from oilseed rape or field beans, supports the findings by Rundlof et al, (2015) that field level exposure has no detectable impact on colony health. However, as this study was undertaken before the current restrictions on neonicotinoids, it is possible that perceptions of neonicotinoid impacts on colonies may have changed since.

There are also notable opportunity costs in supplying hives for oilseed rape, despite it's 
relatively high nectar availability. However, as honey production varies throughout the year, it is possible that the honey produced during the early oilseed rape flowering season may be in a below average production month, resulting in costs being overestimated. By contrast, depreciation of honey producing strength was not considered to be a substantial factor by most respondents, even in apples which are often considered poor nectar sources (Free, 1993). Although informative, these results would benefit from a more detailed and systematic examination of the specific costs of beekeeping for pollination, such as the costs of vehicular hire, any variation in payments received from growers of different scales and the value of honey sales contracts.

\subsection{Benefits of pollination services}

Comparing the costs of providing pollination services with the benefits received by apple orchards highlights that the payments typically received 86-149 times smaller than the monetary benefits of the pollination services provided. Although based on observed field data, it is likely that successive hives will provide diminishing marginal benefits (Garratt et al., 2016). Furthermore there is considerable uncertainty within the literature regarding the recommended stocking rates, due to differences in stocking rates, system inputs and estimation methods (Breeze et al., 2014) as well as varietal differences in polliniser compatibility (Matsumoto et al., 2007) and floral morphology (Free, 1993). As such, the findings indicate that a better understanding of the relationship between honeybee stocking rates and pollination services could lead to the development of pricing schemes for professional pollination services that better reflect the benefits of pollination services.

\subsection{Broader Implications}

Although exploratory, the findings of this study highlight three future avenues for further research, development of pollination service markets, and policy support into the economics of UK beekeeping. Foremost, the results indicate that few amateurs provide pollination services to crops, despite most amateurs being located in crop heavy regions of England. Understanding both the finer costs of providing services and the motivations for doing so among these amateurs may allow policy to create more opportunities for amateur beekeepers to supply hives to local farmers, particularly smaller enterprises. As of 2010 , the UK has only $20 \%$ of the honeybee hives required to provide optimal pollination services, despite the growing demands for pollination services from oilseed rape and field beans (Breeze et al., 2014). While many producers rely upon wild pollinators to provide the majority of their service needs (Garratt et al., 2016), the use of managed honeybees could be effective at reducing yield gaps if wild pollination services are insufficient to provide maximum output, as observed in gala apples (Garratt et al., 2014). However, some caution should also be exercised to avoid over-pollination where wild pollinators are already adequate, possibly resulting in producer losses (e.g. cox apples, Garratt et al., 2014) and benefits are likely to be much smaller in lower priced arable crops (e.g. Bommarco et al., 2012). Stronger monitoring of pollinator populations (e.g. Carvell et al., 2016) and sedentary honeybee hives could therefore facilitate bee farmers adopting a more demand (based on likely services shortfalls; e.g. Polce et al., 2014) and benefit (based on output gains) driven based pricing scheme that more accurately reflects the value of managed pollination services.

Secondly, the findings indicate that some beekeepers, including professionals, are providing pollination services at a net loss and that few beekeepers are able to extract quantities of honey comparable to non-crop habitats. Although possibly in part a reflection of the assumptions made in 
the survey, the findings nonetheless highlight the importance of payments to offset the potential limitation in honey harvest, a key driver in pollination service prices in the USA (Rucker et al., 2012). Further research into farmer willingness to pay for pollination services, particularly from arable farmers, whos large fields are unlikely to receive adequate pollination from semi-natural habitat alone (Rader et al., 2009; Garibaldi et al., 2011), has the potential to incentivise better payments for pollination services outside of arable crops. However, this may be complicated by the relatively limited impact of pollination services on productivity in these crops (e.g. Bommarco et al., 2012). Finally: the necessity of using a questionnaire element is due largely to the lack of data collection on bee farming as an agricultural sector. Although the results demonstrate that amateur beekeepers do provide pollination services and experience costs in doing so, most beekeepers providing services were professionals that often supplied larger numbers of hives. Unlike other farming sectors in the UK however (e.g. DEFRA, 2016, FBS, 2016), there is no systematic collection of enterprise data for bee farming. Systematically measuring the costs and business performance of the small number of professional beekeepers in the UK as with other farming sectors would therefore give an insight into the financial factors affecting both the UK's honey market and a majority of the pollination service market.

\section{References}

Baude M., Kunin W.E., Boatman N., Conyers S., Davies N., Gillespie M.K.A., Morton R.D., Smart S.M. and Memmott J. (2015) Historical nectar assessment reveals the fall and rise of floral resources in Britain; Nature 530, 85-88

Breeze T.D., Vaissiere B., Bommarco R., Petanidou T., Seraphides N, Kozák L., Scheper J., Biesmeijer J.C., Kleijn D., Gyldenkærne S., Moretti. M., Holzscuh A., Steffan-Dewenter I., Stout J., Pärtel M., Zobel M. and Potts S.G. (2014) Agricultural Policies Exacerbate Honeybee Pollination Service SupplyDemand Mismatches Across Europe; PLoS One 9, e82996 DOI: 10.1371/journal.pone.0082996

Bommarco R., Marini L. and Vaissiere B. (2012) Insect pollination enhances seed yield, quality, and market value in oilseed rape; Oecologica 169, 1025-1032

British Beekeepers Association (BBKA) (2016) Winter Survival Survey (Press Release, original document not publicly accessible)

http://www.bbka.org.uk/files/pressreleases/winter survival release 2016 (2) 1469182251.docx published $21 / 07 / 16$

Carreck N.L., Williams I.H. and Little D.J. (1997) The Movement of honey bee colonies for crop pollination and honey production by beekeepers in Great Britain; Bee World 78, 67-77

Carvell et al., (including Breeze T.D.) (2016) Design and Testing of a National Pollinator and Pollination Monitoring Framework http://randd.defra.gov.uk/Default.aspx?Menu=Menu\&Module=More\&Location=None\&Completed= 2\&Project $\mid \mathrm{D}=19259$

Delaplane K.S. and Mayer D.E. (2000) Crop Pollination by Bees, CABI Publishing; Wallingford. 

chapter07-06jun13.xls last updated 26/05/16

DEFRA (2016b) Horticulture Statistics 2015 https://www.gov.uk/government/statistics/horticulturestatistics-2015 last updated 22/07/16

DEFRA (2016c) Structure of the agricultural industry in England and the UK at June https://www.gov.uk/government/statistical-data-sets/structure-of-the-agricultural-industry-inengland-and-the-uk-at-june Last updated 20/12/16

DEFRA (2015) National Pollinator Strategy: Implementation Plan https://www.gov.uk/government/uploads/system/uploads/attachment data/file/474386/npsimplementation-plan.pdf

DEFRA (2014) The National Pollinator Strategy: for bees and other pollinators in England https://www.gov.uk/government/uploads/system/uploads/attachment data/file/409431/pb14221national-pollinators-strategy.pdf

359 Doublet V., Labarussias M., de Miranda J.R., Moritz R. and Paxton R. (2015) Bees under stress:

360 sublethal doses of a neonicotinoids pesticide and pathogens interact to elevate honey bee mortality across the life cycle; Environmental Microbiology 17, 969-983

Farm business Survey (2016) Farm Business Survey Data builder,

363 http://www.farmbusinesssurvey.co.uk/DataBuilder/

FAO (2017a) Production - Livestock Primary http://www.fao.org/faostat/en/\#data/QL last updated $13 / 02 / 17$

FAO (2017b) Prices - Livestock Primary http://faostat3.fao.org/faostatgateway/go/to/download/P/*/E, accessed 20/08/14

FERA (2013) South East Region Honey Survey 2013

https://secure.fera.defra.gov.uk/beebase/downloadDocument.cfm?id=911 accessed 20/08/14

370 FERA (2011) South East Region Honey Survey 2011

371 https://secure.fera.defra.gov.uk/beebase/downloadDocument.cfm?id=582 accessed 20/08/14

Free J (1993) Crop Pollination by Insects (2nd Edition), Academic Press, London.

373 Garibaldi L.A. et al (2011) Stability of pollination services decreases with isolation from natural areas despite honey bee visits; Ecology Letters 14, 1062-1072

375 Garibaldi L.A. et al (2013) Wild pollinators enhance fruit set of crops regardless of honey-bee

376 abundance; Science 339, 1608-1611

377 Garratt M.P., Breeze T.D., Jenner N., Polce C., Biesmeijer J.C and Potts S.G. (2014) Avoiding a bad 378 apple: insect pollination enhances fruit quality and economic value; Agriculture, Ecosystems and 379 Environment 184, 34-40 
Garratt M.P., Breeze T.D., Boreaux V., Fountain M.T., McKerchar M., Webber S.M., Coston D.J., Jenner N., Dean R., Biesmeijer J.C and Potts S.G. (2016) Apple pollination: Demand depends on cultivar and supply depends on pollinator identity; PLoS1 11(5): e0153889.

Godfray H.C.J., Blacquiere T., Field L.M., Hails R.S., Pterowfsky G., Potts S.G., Raine N.E., Vanbergen A.J. and McLean A.R. (2014) A Restatement of the Evidence Base Concerning Neonicotinoid Insecticides and Insect Pollinators; Proceedings of the Royal Society B - Biological Sciences 281, 20140558

Godfray H.C.J., Blacquiere T., Field L.M., Hails R.S., Potts S.G., Raine N.E., Vanbergen A.J. and McLean A.R. (2015) A Restatement of Recent Advances in the Natural Science Evidence Base Concerning Neonicotinoid Insecticides and Insect Pollinators; Proceedings of the Royal Society B - Biological Sciences 282, 20151821

Klein A.M., Vaissière B.E., Cane J.H., Steffan-Dewenter I., Cunningham S.A. et al (2007) Importance of Pollinators in Changing Landscapes for World Crops; Proceedings of the Royal Society of London BBiological Sciences 274, 303-313.

Matsumoto S., Eguchi T., Bessho H. and Abe K. (2007) Determination and Confirmation of S-Rnase Genotypes of Apple Pollinators and Cultivars; Journal of Horticultural Science and Biotechnology 82, (2), 323-329

Office of National Statistics (2014) Weekly Fuel prices https://www.gov.uk/government/statisticaldata-sets/oil-and-petroleum-products-weekly-statistics accessed 20/08/14, last updated 07/05/14

Pettis J.S., vanEngelsdorp D., Johnson J. and Dively G. (2012) Pesticide exposure in honey bees results in increased levels of the gut pathogen Nosema; Naturwissenschaften 99, 153-158

Polce C., Termansen M., Aguirre-Gutierrez J., Boatman N.D., Budge G.E., Crowe A., Garratt M.P., Pietravalle S., Potts S.G., Ramirez J.G., Somerwill K.G. and Biesmeijer J.C., (2014) Species Distribution Models for Crop Pollination: A Modelling Framework Applied to Great Britain; PLoS One 8, e76308

Potts S.G., Roberts S.P.M., Dean R., Marris G. and Brown M.A. et al (2010) Declines of managed honeybees and beekeepers in Europe; Journal of Apicultural Research 49, 15-22.

Rader R., Howlett B.G., Cunningham S.A., Westcott D.A. and Newstrom-Lloyd L.E. et al (2009) Alternative Pollinator Taxa are Equally Efficient but not as Effective as the Honeybee in a Mass Flowering Crop; Journal of Applied Ecology 46, 1080-1087

Rundlof M., Andersson G.K.S., Bommarco R., Fries I., Hederstrom V., Herbertsson L., Jonsson O., Klatt B.K., Pedersen T.R., Yourstone J. and Smith H.G. (2015) Seed coating with a neonicotinoid insecticide negatively affects wild bees; Nature 521, 77-80

Rucker R.R., Thruman W.H. and Burgett M. (2012) Honeybee pollination markets and the internalisation of reciprocal benefits; American Journal of Agricultural Economics 94, 956-977

Vanbergen A., Heard M.S., Breeze T.D., Potts S.G. and Hanley N. (2014) Status and Value of Pollinators and Pollination Services - A report to the Department of Environment Food and Rural Affairs (DEFRA) https://consult.defra.gov.uk/plant-and-bee-health-policy/a-consultation-on-the- 
417 national-pollinator-

418 strategy/supporting documents/140314\%20STATUS\%20AND\%20VALUE\%200F\%20POLLINATORS\%2

419 OAND\%2OPOLLINATION\%20SERVICES FINALver2.pdf

420 VCA (2016) Van CO2 and Fuel Consumption database http://vanfueldata.dft.gov.uk/vehicles.aspx ,

421 last updated $25 / 10 / 16$

422 Veterinary Medicines Directorate (2013) Action Plan on the Availability of Medicines for Bees;

423 http://www.vmd.defra.gov.uk/pdf/bee actionplan.pdf last accessed 20/08/14, last updated

$42401 / 08 / 13$

425 Wilfert L., Long G., Leggett H.C., Schmid-Hempel P., Butlin R., Martin S.J.M. and Boots M (2016)

426 Deformed wing virus is a recent global epidemic in honeybees driven by Varroa mites; Science 351,

$427 \quad 594-597$

428 Winfree R, Aguilar R, Vazquez DP, LeBuhn G and Aizen M (2010) A meta-analysis of bees' responses

429 to anthropogenic disturbance; Ecology 90, 2068-2076.

430 Acknowledgements

431 The authors thank the many beekeeping associations and the Bee Farmers Association for helping

432 distribute the survey. Jennifer Wickens, Maria Zhang and two anonymous reviewers provided helpful

433 comments on earlier drafts of this manuscript. This research was funded received funding from the

434 CB Dennis Trust for Beekeepers and the European Community's Seventh Framework Programme

435 (FP7/2007-2013) under grant agreement no 244090, STEP Project (Status and Trends of European

436 Pollinators: www.step-project.net). 